\title{
Antecedents impact on brand loyalty in cosmetics industry
}

\begin{abstract}
This study aimed to examine antecedents' impact on brand loyalty in a highly competitive of cosmetics industry dealing with a mass majority of younger consumers. The study also addressed the relationship between perceived value and customer satisfaction on the effect of brand loyalty. Women or men purchasing and personally using cosmetic products were participants of this study. Data gathered from a total sample of 200 women or men from multiple ethnicities such as Malayans, Chinese and Indians were used for the statistical analysis. It was collected from main shopping mall centers in Klang Valley. Multiple regression analysis was applied to test relationship between brand loyalty, perceived value and customer satisfaction. Besides that, it tested perceived value, corporate image and service quality and customer satisfaction relationships. The results demonstrated that the perceived value and customer satisfaction had significant influence on brand loyalty; particularly, overall customer satisfaction did influence loyalty intention. As a matter of fact, by maintaining and strengthening its images and values, brand would be positively positioned in the minds of consumers.
\end{abstract}

Keyword: Brand loyality; Customer statisfaction; Service quality; Perceived value; Corporate image 